\title{
PEMBELAJARAN UNSUR IRAMA MENGGUNAKAN METODE TAKADIMI PADA MAHASISWA PAUD FIP UNY TAHUN AJARAN 2015/2016
}

\author{
Oleh: \\ Rina Wulandari \\ wulandaririna80@gmail.com \\ Jurusan PAUD FIP UNY
}

\begin{abstract}
Abstrak
Penelitian ini bertujuan mengeksplorasi pelaksanaan pembelajaran unsur irama musik menggunakan metode Takadimi pada mahasiswa prodi PAUD FIP UNY tahun ajaran 2015-2016. Subjek penelitian yaitu 83 mahasiswa. Penelitian ini menggunakan pendekatan kualitatif dengan jenis penelitian yaitu eksplorasi. Teknik penyajian data yaitu deskriptif. Teknik pengumpulan data menggunakan observasi, wawancara, dan dokumentasi. Teknik keabsahan data adalah dengan ketekunan. Hasil penelitian dalam mata kuliah estetika instrumental: 1) peserta didik adalah lulusan dari berbagai jurusan dan didominasi oleh lulusan sekolah menengah atas, 2) tujuan pembelajaran berbasis pada konsep dasar pendidikan seni untuk AUD yaitu menstimulasi estetika melalui apresiasi dan kreasi ekspresi, 3) materi musik menggunakan metode Takadimi yang termasuk metode untuk semua kalangan, 4) metode pembelajaran yang digunakan adalah ceramah, tanya jawab, diskusi, pemberian tugas, demonstrasi dan eksperimen, kerja kelompok, drill, dan penemuan, 5) media pembelajaran yang digunakan adalah piano serta semua benda yang ada di sekitar yang dapat diatur menjadi bunyi musikal, dan 6) evaluasi didasarkan pada tugas, kehadiran, nilai ujian tengah semester, dan nilai ujian semester. Temuan lain selama penelitian yaitu: 1) kuantitas suku kata TA yang diganti dengan nol, merupakan hal yang sulit dibunyikan/ dipraktekkan oleh mahasiswa, dan 2) bentuk TA00MI dan TAKA0MI.
\end{abstract}

Kata kunci: pembelajaran, unsur irama musik, metode takadimi

\begin{abstract}
The research is aimed to explore the implementation of musical rhyme learning using Takadimi method to the students of PAUD department, FIP, UNY in the 2015-2016 academic year. The research subjects are 83 students. Approach used in the research is qualitative research approach namely exploration. The data is presented descriptively. The data is obtained using observation, interview, and documentation. Perseverance is used as the data validation. The research result showed that: 1) students are graduates from various major, dominantly from senior high school, 2) learning objective is grounded on the basic concept of art education for early childhood students which is to stimulate the aesthetic aspect through appreciation and expression of creation, 3) the music learning material using Takadimi method is classified as general for all level, 4) learning methods used are lecturing, question-and-answer, discussion, assignments, demonstration and experiment, group work, drilling, and invention, 5) learning media used are piano and any objects having musical sound, and 6) evaluation is taken and based on the assignments, attendance, mid semester test result, and the final or semester test. Other findings during the research are: 1) the difficulty of the students to sound and practice the syllable quantity TA which is substituted with zero, and 2) the form of TAOOMI and TAKAOMI. Keywords: learning, musical rhyme element, Takadimi method
\end{abstract}

\section{PENDAHULUAN}

Bicara tentang musik, berarti bicara tentang bunyi dan suara yang musikal.
Musikal setidaknya dapat diberikan contoh yaitu suara knalpot massa saat pesta demokrasi. Tentu para pembaca sangat 
mudah mengingat peristiwa yang terjadi setiap pesta pemilihan umum tersebut. Berbagai suara knalpot berbunyi bergantian dengan detik yang teratur. Itulah contoh kecil dari bunyi yang musikal sehingga kita dapat membandingkan dengan bunyi yang tidak teratur.

Bunyi dan suara sedikit mempunyai perbedaan. Bunyi mencakup segala sesuatu di sekitar kita yang dapat menghasilkan bunyi dengan cara dipukul, disentuhkan satu sama lain, digesek, ataupun berbunyi karena alam itu sendiri. Contoh: bunyi kentongan, bunyi bel, bunyi kendaraan, bunyi gemercik air, bunyi hujan, dan semacamnya.

Suara lebih dimaknai sebagai bunyi yang berasal dari bergetarnya organ pita suara yang ada di leher, tepatnya sekitar kerongkongan manusia, sehingga contoh spesifik dari suara adalah saat menyanyi.

Bunyi dan suara merupakan salahsatu hal yang ada di sekitar anak yang dapat digunakan sebagai salahsatu alat mendidik. Mendidik merupakan kegiatan yang disengaja dengan tujuan menjadikan peserta didik berada pada keadaan 'tidak tahu' menjadi 'tahu' disertai dengan adanya perubahan nilai, moral, sikap menuju yang lebih baik. Siapakah yang bertugas mendidik anak-anak bangsa ini? Diantaranya adalah keluarga, sekolah, dan masyarakat. Guru merupakan salah satu unsur pendidik bagi anak yang tentunya harus memiliki kemampuan untuk melakukan hal tersebut.

Berdasarkan uraian tersebut, maka, tenaga pendidik AUD pada khususnya, haruslah memiliki kemampuan/ kompetensi sejalan profesi yang sedang dijalankan/ kompetensi professional. Sejenak jika kita lihat kembali kemampuan yang seharusnya dimiliki oleh tenaga pendidik AUD, yaitu terdapat pada kutipan berikut, Peraturan Menteri Pendidikan Nasional (Permendiknas) Nomor 58 Tahun 2009 tentang Standar PAUD yang menyebutkan rentang dan kompetensi professional tenaga pendidik AUD, yaitu:

Undang-undang Nomor 20 Tahun 2003 tentang Sistem Pendidikan NasionalPasal 1 angka 14 menyatakan bahwa Pendidikan Anak Usia Dini (PAUD) adalah suatu upaya pembinaan yang ditujukan kepada anak sejak lahir sampai dengan usia enam tahun yang dilakukan melalui pemberian rangsangan pendidikan untuk membantu pertumbuhan dan perkembangan jasmani dan rohani agar anak memiliki kesiapan dalam memasuki pendidikan lebih lanjut memahami tahapan perkembangan anak.

Terkait kompetensi professional tenaga pendidikan AUD tersebut, maka, lulusan jurusan PAUD FIP UNY juga hendaknya mendukung terwujudnya kompetensi tersebut. Perkembangan anak mencakup semua aspek perkembangannya, yaitu aspek pemahaman nilai-nilai agama dan moral, fisik, kognitif, bahasa, dan sosialemosional.

Terkait aspek perkembangan tersebut, seni memang tidak muncul secara eksplisit, namun pada aspek yang lain, diantaranya aspek bahasa pada tingkat pencapaian perkembangan anak mampu menyanyikan lagu sederhana. Menyanyi merupakan suara terkait kata-kata, yang dapat berupa puisi bersajak, yang dikenai nada dan irama.

Berdasarkan hal tersebut maka tenaga pendidik AUD juga hendaknya mempunyai kemampuan untuk dapat menyanyi dengan tepat nada dan iramanya. Sejalan dengan hal ini, seharusnya, mahasiswa pada jurusan Pendidikan Anak Usia Dini (PAUD) yang akan menempuh mata kuliah estetika instrumental untuk anak usia dini, telah memiliki kemampuan musik 
yaitu kepekaan bunyi berirama dan ketepatan menyuarakan melodi. Meskipun materi seni musik di jurusan PAUD tidak sedalam di jurusan pendidikan seni musik pada umumnya, namun kemampuan musik tersebut sangat penting dimiliki mahasiswa. Memang benar juga bahwa lulusan PAUD nantinya tidak menjadi lulusan yang menguasai satu alat musik seperti di jurusan pendidikan seni musik.

Kenyatannya, masih terdapat mahasiswa yang kurang optimal pada kemampuan musikalnya. Pada umumnya, mahasiswa mampu menirukan bunyi berirama yang peneliti contohkan. Kurang optimalnya kemampuan mahasiswa terletak pada pengetahuan tentang penciptaan ragam bunyi berirama. Hal ini berdasar pada penelitian terdahulu yaitu survey di jurusan Pendidikan Guru Sekolah Dasar (PGSD) dan PAUD. Berdasarkan survey tersebut, didapatkan data bahwa, pada umumnya, mahasiswa yang lahir pada tahun 1993, tidak didapati adanya ketidaktepatan dalam memainkan bunyi yang berirama. Survey dilakukan dengan cara, dosen memberikan contoh bunyi berirama menggunakan tepukan tangan sedangkan mahasiswa kemudian disilahkan untuk menirukan.

Seharusnya, minat mahasiswa jurusan PAUD terhadap mata kuliah musik juga homogen/ sama-sama berminat. Kenyataannya, minat beberapa mahasiswa terhadap mata kuliah seni musik mengalami kekurangoptimalan karena faktor pengalaman yang kurang positif pada masa kecil.

Berdasarkan survey yang peneliti lakukan, bermacam faktor ketidakminatan mahasiswa terhadap mata kuliah musik sehingga kemampuan musik kurang optimal, diantaranya yaitu:

1. Beberapa mahasiswa mengalami hal yang kurang mendidik pada saat ia menempuh pendidikan di lembaga sekolah dasar. Guru dan teman- temannya menertawai ketika salah ataupun lupa mengucapkan syair lagu yang dilakukan dalam pengambilan nilai ujian akhir mata pelajaran kesenian.

2. Orangtua dari mahasiswa yang bersangkutan selalu marah ketika ia melakukan aktivitas musikal (menyanyi ataupun mengetuk-ngetuk sesuai irama).

Seharusnya, sebagai calon stimulator kemampuan musik untuk AUD, mahasiswa hendaknya memiliki kemampuan menyanyi awal, misalnya: tidak fals saat menyanyi.

Kenyataannya, berdasarkan pelaksanaan survey dan dalam pembelajaran pada setiap kali tatap muka, mahasiswa cenderung dapat menirukan nada dengan baik apabila susunan nada yang mereka dengar berjumlah sedikit dan intervalnya jenis melangkah. Sebagai contoh: peneliti membunyikan/ menyuarakan urutan suara tiga nada, yaitu nada do (1), re (2), dan mi (mi). Pada umumnya, mahasiswa dapat menirukan suara tersebut dengan benar. Berbeda halnya ketika rangkaian nada dengan kuantitas interval melompat, yaitu dari nada (do) melompat ke nada 4 (fa). Mahasiswa banyak yang belum optimal.

Berdasarkan beberapa kesenjangan tersebut, maka, melalui deskripsi kualitatif ini, peneliti bermaksud menceritakan pembelajaran unsur irama menggunakan metode Takadimi.

\section{DEFINISI IRAMA}

Bunyi yang ada disekitar kita dapat dijadikan bunyi yang mengandung musik. Sebagaimana kita ketahui bahwa hakikat musik adalah bunyi. Bunyi adalah ( Bruce Benward and Marilyn Saker: xiii) "Sound is the sensation perceived by the organs of hearing when vibrations (sound waves) reach the ear). (Bunyi adalah rasa/ tanggapan indra organ pendengaran ketika getaran (gelombang bunyi) mencapai/ sampai ke telinga) 
Andainya, musik diumpamakan masakan, maka terdapat bahan-bahan pembentuk. Bahan pembentuk musik diantaranya yaitu Safriena (1999:1) menyebutkan bahwa irama merupakan bagian dari unsur musik. Unsur musik terdiri atas: irama, melodi, harmoni, frasering/ bentuk lagu, dan ekspresi. Irama merupakan unsur dasar musik. Irama terbentuk dari perpaduan sekelompok bunyi dan diam dengan bermacam-macam lama waktu atau panjang pendeknya (Safriena:1999:168169). Irama berkaitan dengan kecepatan atau tempo. Irama mencakup sub yaitu: pulsa/ ketukan, birama, dan pola irama.

Berdasarkan kutipan tersebut maka pengertian irama adalah salah satu unsur musik dimana irama/ ritme merupakan unsur paling dasar dalam musik. Irama terbentuk dari perpaduan sekelompok bunyi dan diam dengan bermacam-macam lama waktu dan panjang pendek (tempo) serta adanya aksen dalam ketukan/ pulsa yang ditunjukkan. Irama mencakup pulsa/ ketukan, birama, dan pola irama. Ketentuan pola ritmenya dinyatakan dengan nama seperti: wals, mars, bossanova, dan lainnya.

Berdasarkan kesimpulan pengertian irama tersebut masih diuraikan lagi mengenai istilah-istilah seperti: tempo, aksen, pulsa/ ketukan, birama, dan pola irama. Berikut uraian selengkapnya. Pendapat pertama mengenai tempo adalah Miller (TT :24) yang menyatakan bahwa "tempo, sebuah istilah dari bahasa Itali yang secara harafiah berarti waktu, di dalam musik menunjukkan pada kecepatan. Musik dapat bergerak pada kecepatan yang sangat cepat, sedang, atau lambat, serta dalam berbagai tingkatan diantara semua itu".

Pendapat kedua tentang tempo adalah Safriena (1999:169) yang menyebutkan bahwa: "tempo adalah kecepatan gerak ketukan dalam lagu; lambat seperti ayunan bandulan yang panjang dari sebuah jam besar, atau cepat seperti ayunan bandulan jam dinding".

Berdasarkan dua pendapat mengenai tempo tersebut maka dapat disimpulkan bahwa tempo adalah istilah dari bahasa Itali yang secara harafiah berarti waktu, di dalam musik menunjukkan pada kecepatan dalam karya musik, yang terdapat dalam ukuran langkah tertentu.

Mengenai pengertian moderato sebagai tempo sedang, Safriena (1999:273) menyatakan bahwa: "Istilah-istilah ini menggunakan bahasa Itali, tetapi sekarang sudah menjadi istilah musik yang resmi dipakai secara umum". Selanjutnya Safriena (1999:273) menyatakan bahwa tempo Moderato berarti sedang. Miller (TT: 24) menyatakan bahwa tempo Moderato berarti kecepatan sedang.

Kaitannya dengan Metronom, istilah kedua setelah tempo adalah "aksen". (Miller, TT:28) menyatakan: " tekanan atau penekanan atas sebuah nada untuk membuatnya berbunyi lebih keras disebut aksen. Aksen dapat bersesuaian dengan pola metrik yang diletakkan pada ketukan pertama dari setiap birama. Aksen juga dapat muncul pada ketukan-ketukan lainnya dari sebuah birama. Muncul pada nada yang mana saja dalam suatu rangkaian ketukanketukan yang berulang-ulang secara teratur, ia menghasilkan ritme".

Berdasarkan kutipan di atas maka pengertian aksen adalah tekanan kuat/ keras atas sebuah nada yang bersesuaian dengan pola metrik yang diletakkan pada ketukan pertama dari tiap birama dan menghasilkan ritme.

Istilah berikutnya adalah pulsa/ ketukan. Safriena (1999:168) sebagai cakupan unsur irama adalah rangkaian denyutan berulang-ulang yang berlangsung secara teratur yang dapat dirasakan dan dihayati dalam musik. Miller (TT:25) menyatakan bahwa ketika mendengarkan musik yang terasa adalah 
denyutan-denyutan yang apabila dalam tempo cepat akan menghasilkan denyutan yang banyak dan sebaliknya. Dari hal ini dapat disimpulkan bahwa pulsa/ ketukan adalah denyutan yang berulang-ulang dan teratur dalam cepat-lambatnya masingmasing.

Istilah berikutnya adalah birama yang artinya ayunan gerak kelompok beberapa pulsa dimana pulsa pertama mendapatkan aksen (tekanan) kuat dibandingkan yang lainnya, berlangsung secara teratur dan berulang-ulang serta mempunyai jenis yaitu: birama dua, birama tiga, birama empat yang disebut birama sederhana (Safriena, 1999:169). Berdasarkan kutipan ini maka dapat disimpulkan bahwa birama adalah ayunan gerak kelompok beberapa pulsa (bisa dua pulsa, tiga pulsa, dan seterusnya) dimana pulsa pertama mendapatkan tekanan kuat dibanding yang lainnya. Ayunan gerak pulsa ini berlangsung secara teratur dan berulangulang. Jenis birama ini bermacam-macam berkaitan dengan namanya yaitu: birama dua, birama tiga, birama empat dimana ketiga birama ini disebut birama sederhana.

Penjelasan istilah terakhir yaitu pola irama. Safriena (1999:177) menyatakan bahwa pola irama mempunyai padanan kata yaitu ostinato irama yang artinya pola irama yang dibunyikan atau didengar berulangulang.

Safriena menambahkan bahwa jika pola irama yang berulang-ulang lebih dari satu macam maka disebut ostinati irama (irama jamak). Berdasarkan pendapat ini maka dapat disimpulkan bahwa pola irama mempunyai padanan kata yaitu ostinato irama yang artinya pola ritme yang dibunyikan atau didengar berulang-ulang dan berlangsung secara teratur sepanjang lagu sehingga membentuk satuan irama dengan nama tertentu.

Bunyi dan suara sedikit mempunyai perbedaan. Bunyi lebih pada getaran yang dihasilkan dari benda non organ pita suara sedangkan suara lebih kepada bergetarnya pita suara pada kerongkongan.

Terkait kata 'untuk anak usia dini', maka matakuliah estetika instrumental untuk anak usia dini, segala unsur musiknya dikaitkan dengan perkembangan anak.

Seni dalam pendidikan tentulah sedikit berbeda dengan seni dalam pembelajaran sehinggga konsep yang digunakan adalah pendidikan seni. Mengapa pendidikan seni, bukan seni pendidikan? Hal ini dikarenakan, seni dalam dunia pendidikan digunakan sebagai pendekatan/ strategi/ metode/ teknis untuk mencapai tujuan pendidikan. Cakupan konsep pendidikan seni ini membahas tentang apresiasi dan kreasi ekspresi sebagai cara untuk mengembangkan ataupun menstimulasi estetika pada anak usia dini. Termasuk pada sub aplikatif, kesejarahan, problematik, dalam apresiasi seni serta produksi dan reproduksi dalam kreasi ekspresi. Seperti telah diketahui bahwa konsep dasar pendidikan seni untuk anak usia dini adalah menstimulasi estetika melalui apresiasi dan kreasi ekspresi.

Pembelajaran untuk mahasiswa PAUD FIP UNY, peneliti pertimbangkan, perlunya mengenalkan dan membelajarkan unsur irama musik terlebih dahulu sehingga pembelajaran pada unsur selanjutnya (melodi, harmoni, frasering, dan ekspresi) mudah dilakukan.

Di lapangan, tentunya banyak sekali metode pembelajaran musik yang telah dihasilkan oleh ahli. Salahsatunya adalah metode Takadimi. oleh karena itu, materi selanjutnya yang disampaikan adalah metode Takadimi. Sejauh yang peneliti alami dalam belajar sistem notasi, metode Takadimi lebih mudah dipelajari, bahkan oleh orang yang awam tentang musik. Hal ini senada dengan pendapat Ester dkk (2006: 62) yaitu 
"music theorists Richard Hoffman, William Pelto, and John W. White desiged rhythm-pedagogy system called Takadimi that is based on research, learning, theory, and best practice methods. Ones of its most appealing trait is that it can be used with all ages levels and cross general, coral, and instrument music.

Berikut ini gambar naskah pada metode Takadimi (Ester dkk, 2006: 62), yaitu:

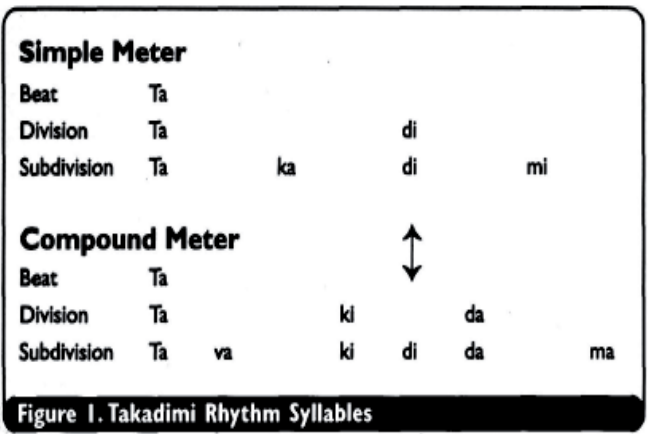

Kemudian, diuraikan lagi dalam gambar berikut (Ester dkk, 2006: 62), yaitu:

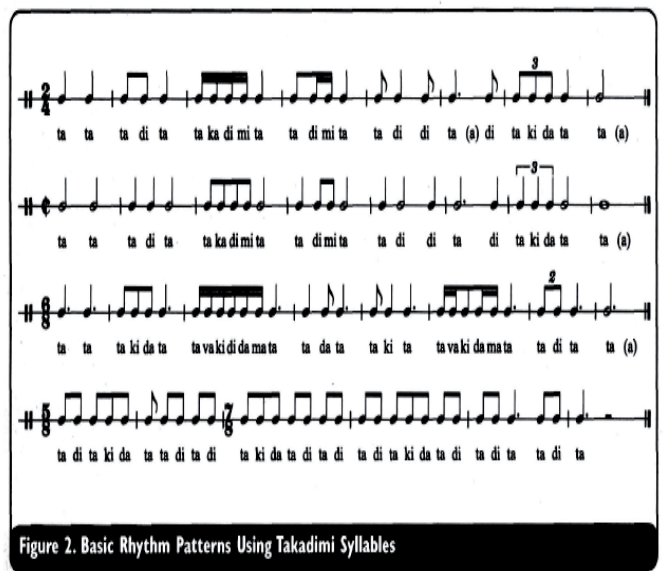

Penelitian ini juga menjabarkan tentang komponen belajar. Berikut kutipan dari beberapa tokoh tentang komponen belajar.

Dalam staff.uny.ac.id/.../default/files/KOMPONEN PEMBELAJARAN_29_3_12.ppt

disebutkan bahwa komponen belajar terdiri dari:
1. Kurikulum, yang terdiri dari: tujuan, materi/ pengalaman belajar, organisasi, dan evaluasi.

2. Guru, yang dijabarkan menjadi: 1) tugas guru secara professional, manusiawi, dan kemasyarakatan, dan 2) peran guru sebagai model, pengajarpembimbing, pelajar, komunikator, pekerja admin.

3. Siswa.

4. Metode belajar, terdiri dari: ceramah, demonstrasi, diskusi, simulasi, tugas, tanya jawab, kerja kelompok, problem solving, team teaching, drill, dan excursion.

5. Materi dan bahan ajar.

6. Media pembelajaran/ alat pembelajaran.

7. Evaluasi

Materi tentang ilmu bentuk musik disampaikan setelah materi metode Takdimi selesai disampaikan. Karl Edmund Prier SJ (1996: 2) mengartikan tentang bentuk musik yaitu:

bentuk musik (form) adalah suatu gagasan/ ide yang nampak dalam pengolahan/ susunan semua unsur musik pada sebuah komposisi.

Bentuk musik dapat dilihat juga secara praktis: sebagai 'wadah' yang 'diisi' oleh seorang komponis dan diolah sedemikian hingga menjadi musik yang hidup.

Istilah dasar dalam ilmu bentuk musik juga mencakup 'kalimat/ periode (Satz)', Prier (1996: 2) menguraikan bahwa 'kalimat' adalah "sejumlah ruang birama (biasanya 8 atau 16 birama) yang merupakan satu kesatuan". Kesatuan tersebut salahsatunya nampak pada akhir kalimat, yang di akhir kalimat tersebut timbul kesan 'selesailah sesuatu' karena melodi yang digunakan termasuk salahsatu anggota dari akor tonika. 
Selanjutnya, Prier menjelaskan bahwa untuk memperlihatkan struktur musik, maka ilmu bentuk memakai sejumlah kode. Kalimat/ periode umumnya memakai huruf besar (A, B, C, dst). Bila kalimat terdapat perulangan yang disertai adanya perubahan, maka huruf besar disertai tanda aksen, misalnya: A B A'.

Prier juga menjelaskan bahwa sebuah kalimat terdiri dari dua anak kalimat/ frase, yaitu:

1. Kalimat tanya/ kalimat depan/ frase antecedens/ question/ vorsatz. Awal kalimat atau sejumlah birama (biasanya 1-4 atau 1-8), disebut 'pertanyaan' atau 'kalimat depan' karena biasanya ia berhenti dengan kesan nada yang mengambang, dapat disebut 'koma', pada umumnya berakor Dominan, terkesan musik yang belum selesai.

2. Kalimat jawaban/ kalimat belakang/ frase consequens/ answerl Nachsatz. Pada umumnya berada pada birama 5-8 atau 9-16. Berhenti di akor tonika.

Lebih lanjut, Prier menguraikan tentang istilah 'Simetri'. Dalam istilah tersebut, musik dirasa enak apabila tersusun/ teratur dalam keseimbangan atau 'nafas' atau bagian-bagian yang sama panjangnya. Hal ini berlaku dalam kalimat tanya-jawab dan juga motif.

\section{METODE PENELITIAN \\ Pendekatan dan Jenis Penelitian}

Pendekatan penelitian ini menggunakan kualitatif. Jenis penelitian ini menggunakan deskriptif eksploratif. Penelitian deskriptif melakukan analisis hanya sampai taraf deskripsi yaitu menganalisis dan menyajikan data secara sistemik, sehingga dapat lebih mudah dipahami dan disimpulkan. Penelitian eksploratif adalah jenis penelitian yang bertujuan untuk menemukan sesuatu yang baru berupa pengelompokan suatu gejala, fakta dan penyakit tertentu. Penelitian deskriptif eksploratif bertujuan untuk menggambarkan keadaan suatu fenomena. Penelitian ini tidak dimaksudkan untuk menguji hipotesis tertentu tetapi hanya menggambarkan apa adanya suatu variabel, gejala atau keadaan (Arikunto, 2002). http://repository.upi.edu/217/6/S FIS 0807 372 CHAPTER3.pdf.

Dalam alamat http://digilib.uinsby.ac.id/7041/4/bab\%203.p df terdapat kutipan tentang pendekatan penelitan eksplorasi. Dalam uraian pada alamat tersebut diuraikan bahwa penelitian eksplorasi yang bertujuan ingin menggali secara luas tentang sebab-sebab atau hal-hal yang mempengaruhi terjadinya sesuatu.

Berdasarkan dua pendapat tersebut maka peneliti menggunakan pendekatan eksploratif ini karena uraian tentang perolehan bunyi dan berbagai hal yang didapatkan melalui pengamatan.

\section{Tempat dan Waktu Penelitian}

Penelitian ini dilakukan di wilayah Yogyakarta sedangkan waktu pelaksanaan penelitian adalah bulan Maret sampai dengan September 2015.

\section{Subjek Penelitian}

Berbagai bentuk gelas berbahan kaca. Berdasarkan video yang telah peneliti amati, maka, dalam video tersebut terdapat tabung transparan yang secara umum sering disebut gelas. Gelas tersebut memiliki tangkai dan diikat pada meja kayu yang berlubang-lubang, lubang sejumlah gelas. Selain itu, penelitian ini juga mengamati jari tangan sebagai sarana teknik memainkan alat musik yaitu teknik menyentuhkan satu sama lain

\section{Teknik Pengumpulan Data}

Teknik pengumpulan data penelitian ini menggunakan observasi dan dokumentasi. Observasi adalah suatu cara pengumpulan 
data dengan mengadakan pengamatan secara langsung.

Teknik dokumentasi dilakukan diantaranya adalah penggunaan dokumendokumen seperti catatan yang telah lalu terkait kemampuan musik pada anak. Teknik wawancara juga digunakan dalam penelitian ini.

\section{Teknik Analisis Data}

Pada alamat

http://digilib.uinsby.ac.id/7041/4/bab\%203.p $\underline{\mathrm{df}}$ dijelaskan bahwa M Menurut Lexy. J Moleong, analisis data adalah proses mengorganisasikan dan mengurutkan data ke dalam pola, kategori dan satuan uraian dasar sehingga dapat ditemukan tema dan dapat dirumuskan hipotesis kerja seperti yang disarankan oleh data.

\section{Keabsahan Data}

Keabsahan data penelitian ini menggunakan jenis ketekunan pengamatan.

Kisi-kisi yang dijadikan bahan pengamatan mencakup: peserta didik, tujuan, materi, metode, media, dan evaluasi pembelajaran.

\section{HASIL PENELITIAN DAN PEMBAHASAN \\ Hasil Penelitian}

Peserta didik pada mata kuliah estetika instrumental untuk anak usia dini adalah bukan dari mahasiswa jurusan seni musik semacam sekolah menengah musik. Pada umumnya mahasiswa berasal dari sekolah menengah umum dan sekolah kejuruan.

Tujuan pembelajaran terurai dalam silabus mata kuliah yang terdiri dari 36 kali tatapmuka dengan beban 4 SKS. Perumusan tujuan pembelajaran memudahkan dosen dalam memilih dan menyusun bahan ajar, mudah dalam merencanakan penggunaan media, serta mudah dalam merencakanan dan melaksanakan penilaian.
Materi pembelajaran dilakukan dengan beberapa tahap. Tahap pertama, peneliti melakukan paparan tentang arti dari nama mata kuliah, yaitu Estetika Instrumental untuk Anak Usia Dini. Estetika dalam konteks PAUD mempunyai tujuan yaitu kebebasan berekspresi atau kebebasan mengungkapan gagasan yang ada dalam pikiran. Kebebasan berekspresi dapat dilakukan dalam berbagai hal, salahsatunya adalah melalui musik.

Berikut selengkapnya pembahasan terkait materi metode Takadimi. Pembelajaran metode Takadimi peneliti awali dengan pengenalan metode itu sendiri. Berikut selengkapnya. Takadimi dalam konteks pendidikan anak usia dini, peneliti maknai mempunyai empat suku kata, yaitu TA, KA, DI, dan MI. Masing-masing suku kata, dimainkan tepat dalam satu detikan jarum panjang pada jam manual. Keempat suku kata tersebut, dapat dibuat diam pada satu suku kata maupun lebih. Diam pada tiap suku kata disamakan dengan penggunaan simbol nol dalam notasi angka sehingga diharapkan pembelajaran irama menggunakan metode Takadimi ini tidak berlawanan dengan simbol penelitian musik di lapangan. Berikut selengkapnya:

Diam pada satu suku kata

$\begin{array}{ccccc}\text { 1. } & T A & K A & D I & M I \\ \text { 2. } & \mathbf{0} & \mathbf{K A} & \mathbf{D I} & \mathbf{M I} \\ \text { 3. } & T A & 0 & D I & M I \\ \text { 4. } & \text { TA } & \mathbf{K A} & \mathbf{0} & \mathbf{M I} \\ \text { 5. } & T A & K A & D I & 0\end{array}$

$\begin{array}{lcccc}\mathbf{6 .} & \mathbf{0} & \mathbf{0} & \mathbf{D I} & \mathbf{M I} \\ \mathbf{7 .} & \mathbf{T A} & \mathbf{0} & \mathbf{0} & \mathbf{M I} \\ 8 . & T A & K A & 0 & 0 \\ \mathbf{9 .} & \mathbf{0} & \mathbf{K A} & \mathbf{0} & \mathbf{M I} \\ \mathbf{1 0 .} & \mathbf{0} & \text { KA } & \text { DI } & \mathbf{0} \\ 11 . & T A & 0 & D I & 0\end{array}$

12. TA $0 \quad 0 \quad 0$ 


$\begin{array}{ccccc}\text { 13. } & \text { 0 } & \text { KA } & \text { 0 } & \text { 0 } \\ \text { 14. } & \text { 0 } & \text { 0 } & \text { DI } & \text { 0 } \\ \text { 15. } & \text { 0 } & \text { 0 } & \text { 0 } & \text { MI }\end{array}$

Diam pada tiga suku kata

16. $\begin{array}{lllll}0 & 0 & 0 & 0\end{array}$

Dari ke-16 bentuk berbeda dari kata TAKADIMI tersebut, maka, pada bagian huruf yang dicetak tebal/ bold (nomor 2, 4, $6,7,9,10,13,14$, dan 15) merupakan susunan suku kata yang sulit untuk dimainkan/ dipraktekkan.

Berikut ini hasil survey kemudahan belajar irama menggunakan metode Takadimi:

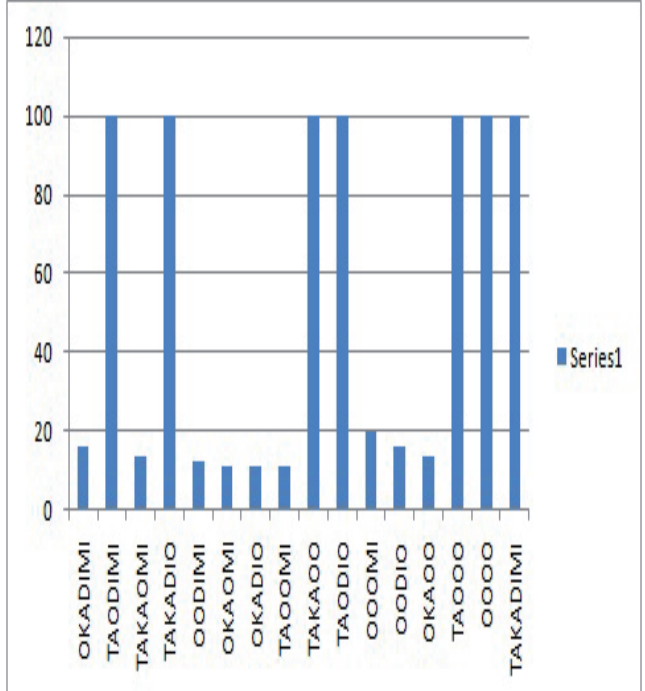

Chart. 1. Prosentase Praktek Metode Takadimi

Berdasarkan chart.1, maka bentuk yang mudah dimainkan adalah TA0DIMI, TAKADI0, TAKA00, TA0DI0, TA000, 0000, DAN TAKADIMI. Mengapa bentuk suku kata TA diganti dengan simbol no (0), sulit untuk dimainkan? Berdasarkan pendapat ahli, dikatakan bahwa, suku kata TA, atau ketuk pertama adalah diam, sulit dimainkan oleh anak-anak. Namun ternyata, jika dipraktekkan oleh orang dewasa sekalipun, bentuk tersebut sulit dipraktekkan.
Berikut ini bentuk takadimi yang mudah untuk dimainkan dan sesuai dengan konteks AUD serta equivalensi dengan nilai dan simbol dalam not balok:

\begin{tabular}{|c|c|c|c|c|}
\hline & TA & KA & DI & MI \\
\hline $\begin{array}{l}\text { Simbol } \\
\text { pada } \\
\text { notasi } \\
\text { balok }\end{array}$ & 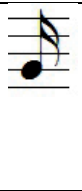 & 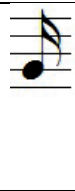 & 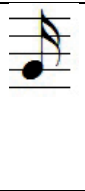 & 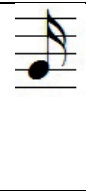 \\
\hline $\begin{array}{l}\text { Penulisan } \\
\text { dengan } \\
\text { cara } \\
\text { digabung }\end{array}$ & & 0 & & \\
\hline
\end{tabular}

\begin{tabular}{|l|c|c|c|c|}
\hline & TA & 0 & DI & MI \\
\hline $\begin{array}{l}\text { Simbol } \\
\text { pada } \\
\text { notasi } \\
\text { balok }\end{array}$ & $\bar{y}$ & $\overline{\bar{y}}$ & $\bar{\vdots}$ & $\bar{\vdots}$ \\
\hline $\begin{array}{l}\text { Penulisan } \\
\text { dengan } \\
\text { cara } \\
\text { digabung }\end{array}$ & \multicolumn{2}{|c}{} \\
\hline
\end{tabular}

\begin{tabular}{|l|c|c|c|c|}
\hline & TA & $\bullet$ & DI & MI \\
\hline $\begin{array}{l}\text { Penulisan } \\
\text { dengan }\end{array}$ & \multicolumn{3}{|c}{} \\
cara \\
digabung
\end{tabular}

\begin{tabular}{|c|c|c|c|c|}
\hline & TA & $\mathrm{KA}$ & DI & 0 \\
\hline $\begin{array}{l}\text { Simbol } \\
\text { pada } \\
\text { notasi } \\
\text { balok }\end{array}$ & 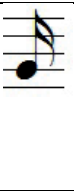 & 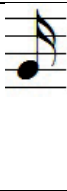 & 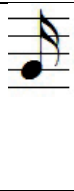 & $\bar{y}$ \\
\hline $\begin{array}{l}\text { Penulisan } \\
\text { dengan } \\
\text { cara } \\
\text { digabung }\end{array}$ & & $\bar{E}$ & & \\
\hline & TA & KA & DI & • \\
\hline
\end{tabular}




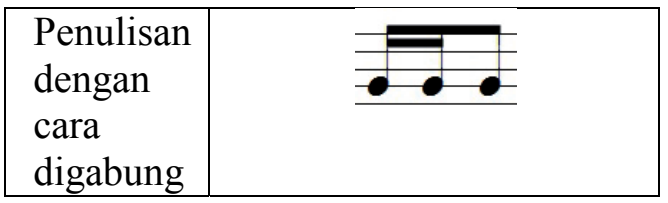

\begin{tabular}{|c|c|c|c|c|}
\hline & TA & KA & 0 & 0 \\
\hline $\begin{array}{l}\text { Simbol } \\
\text { pada } \\
\text { notasi } \\
\text { balok }\end{array}$ & 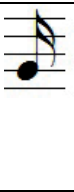 & 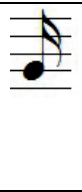 & yै & yै \\
\hline $\begin{array}{l}\text { Penulisan } \\
\text { dengan } \\
\text { cara } \\
\text { digabung }\end{array}$ & & & & \\
\hline
\end{tabular}

\begin{tabular}{|c|c|c|c|c|}
\hline & TA & KA & • & • \\
\hline $\begin{array}{l}\text { Penulisan } \\
\text { dengan } \\
\text { cara } \\
\text { digabung }\end{array}$ & & & & \\
\hline
\end{tabular}

\begin{tabular}{|l|c|c|c|c|}
\hline & TA & 0 & DI & 0 \\
\hline $\begin{array}{l}\text { Simbol } \\
\text { pada } \\
\text { notasi } \\
\text { balok }\end{array}$ & $\bar{\Xi}$ & $\overline{\bar{y}}$ & $\bar{y}$ & $\overline{\bar{y}}$ \\
\hline $\begin{array}{l}\text { Penulisan } \\
\text { dengan } \\
\text { cara } \\
\text { digabung }\end{array}$ & \multicolumn{3}{|c|}{} & yे \\
\hline
\end{tabular}

\begin{tabular}{|c|c|c|c|c|}
\hline & TA & • & DI & • \\
\hline $\begin{array}{l}\text { Penulisan } \\
\text { dengan } \\
\text { cara } \\
\text { digabung }\end{array}$ & & & & \\
\hline
\end{tabular}

\begin{tabular}{|l|c|c|c|c|}
\hline & TA & 0 & 0 & 0 \\
\hline $\begin{array}{l}\text { Simbol } \\
\text { pada } \\
\text { notasi } \\
\text { balok }\end{array}$ & $\bar{\Xi}$ & $\overline{\bar{y}}$ & $\overline{\bar{y}}$ & $\overline{\bar{y}}$ \\
\hline $\begin{array}{l}\text { Penulisan } \\
\text { dengan } \\
\text { cara } \\
\text { digabung }\end{array}$ & \multicolumn{3}{|c|}{} & yे yैy \\
\hline
\end{tabular}

\begin{tabular}{|l|c|c|c|c|}
\hline & TA & $\bullet$ & $\bullet$ & $\bullet$ \\
\hline Penulisan & \multicolumn{4}{|c|}{$\bar{\Xi}$} \\
dengan & \multicolumn{4}{|c|}{} \\
cara & \multicolumn{4}{|}{} \\
digabung & \multicolumn{3}{|}{} \\
\hline
\end{tabular}

\begin{tabular}{|l|l|l|l|l|}
\hline & 0 & 0 & 0 & 0 \\
\hline $\begin{array}{l}\text { Simbol } \\
\text { pada } \\
\text { notasi } \\
\text { balok }\end{array}$ & $\overline{\bar{y}}$ & $\overline{\bar{y}}$ & $\overline{\bar{y}}$ & $\overline{\bar{y}}$ \\
\hline $\begin{array}{l}\text { Penulisan } \\
\text { dengan } \\
\text { cara } \\
\text { digabung }\end{array}$ & \multicolumn{2}{|c|}{} & $\overline{\bar{y}}$ \\
\hline
\end{tabular}

Terkait frasering, maka berdasarkan paparan panjang dari Prier pada kajian teori, maka materi ilmu bentuk, peneliti sampaikan dengan terlebih dahulu dikenalkan terkait Takadimi dan 15 bentuk lain pada aline sebelumnya. Ilmu bentuk dikaitkan dengan tanda birama. Tanda birama dikenal dengan angka pecahan yaitu 2/4, 3/4, 4/4, dan semacamnya. Dalam konteks AUD, berdasarkan pengamatan selama proses perkuliahan, tanda birama yang mudah untuk diikuti/ dipraktekkan adalah jenis 2/4 dan 4/4. Berikut uraian pelaksanaan pembelajaran ilmu bentuk.

Dalam tanda birama $2 / 4$, terdapat angka 2 sebagai jumlah denyut dalam tiap ruas birama sedangkan 4 adalah nilai tiap denyutan. Tanda birama 2 peneliti sampaikan dengan istilah 'bakso super' dan 'cilok', sehingga gambarnya adalah sebagai berikut:

$$
\begin{gathered}
\text { Garis } \\
\text { birama } \\
\text { tunggal } \\
\uparrow \\
/
\end{gathered}
$$

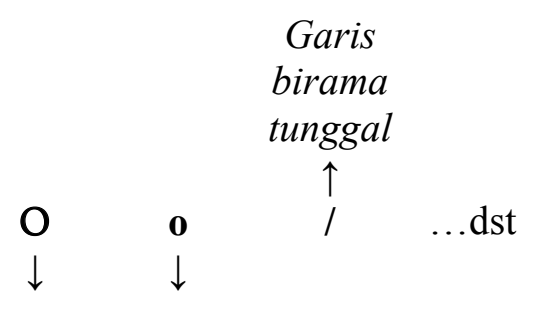




\section{'bakso 'cilok' super'}

Berdasarkan gambar di atas, maka masing-masing 'bakso super' ataupun 'cilok', yang akan diganti menggunakan 5 bentuk dari metode Takadimi beserta equivalensi dalam notasi balok.

Metode pembelajaran yang digunakan adalah ceramah, tanya jawab, diskusi, pemberian tugas, demonstrasi dan eksperimen, kerja kelompok, drill, dan penemuan.

Metode ceramah dilakukan dengan menjelaskan secara lisan terkait materi kuliah. Sebagai contoh dosen memberikan ceramah tentang $5 \mathrm{~W} 1 \mathrm{H}$. What terkait dengan apakah yang dimaksud dengan metode Takadimi. Where terkait dimanakah metode Takadimi pertamakali digunakan. Why terkait dengan mengapa metode Takadimi diberikan kepada mahasiswa PGPAUD. Hal ini secara singkat peneliti sampaikan bahwa metode Takadimi dalam alinea berikutnya disampaikan dengan disesuaikan dengan konteks AUD terkait unsur musik yang ada di dalamnya.

Metode tanya jawab dilakukan dengan cara dosen memberikan pertanyaan terkait materi, misalnya: pendidikan seni ataukah seni pendidikan?. Jenis bentuk takadimi apa saja yang sulit untuk dimainkan? Birama jenis dua, menggunakan berapa simbol denyut? Dan semacamnya.

Metode diskusi dilakukan dengan cara dosen memberikan persoalan, misalnya, konsep birama jenis 2 yang disusun menggunakan metode Takadimi dengan mengikutkan materi ilmu bentuk musik. Hal ini kemudian inklut dalam metode pemberian tugas/ resitasi.

Metode demonstrasi dan eksperimen dilakukan dengan cara dosen memperlihatkan proses pembentukan bentuk lain dari metode Takadimi sehingga menjadi 16 bentuk tersebut dalam aline sebelumnya.
Metode simulasi dilakukan dengan cara menghadirkan situasi tiruan 'bakso super' dan 'cilok' untuk menjelaskan adanya aksen kuat dan ringan dalam tanda birama jenis dua. Contoh lain adalah penjelasan tentang metode Takadimi untuk menjelaskan notasi berharga $1 / 4$ yang terdiri dari 4 notasi $1 / 16$.

Metode kerja kelompok dilakukan dengan cara membagi kelas menjadi beberapa kelompok dengan jumlah genap dengan tujuan agar terjadi komunikasi satu lawan satu. Di kelas lain, pembagian kelompok didasarkan pada jumlah laki-laki yang ada. Pada saat penelitian ini berlangsung, kelas IIIB terdiri dari 5 mahasiswa laki-laki dengan jumlah keseluruhan yaitu 43 mahasiswa. Maka kelas terbagi menjadi sekitar 5 kelompok dengan anggota antara 8-9 mahasiswa.

Metode drill dilakukan dengan cara mengulang-ulang bagian materi yang dianggap sulit. Contoh: selama pembelajaran berlangsung, iringan birama jenis 3 yang digunakan untuk mengenalkan rasa birama jenis 3 menggunakan metode Takadimi merupakan iringan yang cenderung dianggap sulit oleh mahasiswa.

Metode belajar jenis penemuan dilakukan dengan cara menghasilkan komposisi takadimi berbirama jenis 2, 3, dan 4. Kemudian didapatkan data bahwa bentuk TAKADIMI terkadang sulit untuk dimainkan/ dipraktekkan jika digabung dengan bentuk komposisi lain.

Media pembelajaran yang digunakan adalah piano dan berbagai bahan penghasil bunyi yang ada di sekitar kelas yang dapat digunakan sebagai alat musik non vokal.

Evaluasi pembelajaran dilakukan diantaranya dengan menempuh adanya ujian tengah semester dan ujian akhir semester yang dilaksanakan pada tatapmuka ke 16 dan 32 .

Berikut data hasil penelitian terkait sulitnya beberapa bentuk takadimi: 
1. Terkait dengan kuantitas suku kata TA yang diganti dengan nol, maka, hal tersebut sulit dibunyikan/ dipraktekkan oleh mahasiswa. Mahasiswa saja sulit untuk memainkan, apalagi anak-anak.

2. Khusus untuk bentuk TA00MI dan TAKA0MI, dalam kenyataannya, sulit dimainkan. Tentunya, bentuk ini juga dihindarkan untuk anak usia dini. Keduanya sulit dipraktekkan apabila digabung dengan bentuk lain.

\section{Pembahasan}

Menyandingkan hasil penelitian dan teori merupakan aktivitas pada alinea ini. Berdasarkan data hasil penelitian, didapatkan fakta bahwa:

1. Peserta didik/ mahasiswa jurusan PAUD berasal dari lulusan non sekolah kejuruan, semacam sekolah menengah musik. Mahasiswa jurusan PAUD didominasi lulusan sekolah menengah atas (SMA). Hal ini kurang sejalan dengan tujuan konsep dasar pendidikan seni yaitu menstimulasi estetika melalui apresiasi dan kreasi-ekspresi. Untuk mendukung terwujudnya lulusan yang mampu menstimulasi estetika pada anak, seharusnya, minimal, mahasiswa telah memiliki kemampuan kepekaan irama dan ketepatan nada. Namun, hal ini masih terselamatkan berkat input mahasiswa yang lahir pada kisaran tahun 1994, dimana anak yang lahir pada kisaran tahun tersebut mudah mengkonsumsi musik.

8. Tujuan pembelajaran tertulis dalam silabus yang telah disusun oleh pengampu. Hal ini telah sejalan dengan kutipan dari alamat staff.uny.ac.id/.../default/files/KOMPO NEN PEMBELAJARAN_29_3_12.ppt disebutkan bahwa komponen belajar terdiri dari: "Kurikulum, yang terdiri dari: tujuan, materi/ pengalaman belajar, organisasi, dan evaluasi...".

2. Materi pembelajaran adalah penerapan metode Takadimi, dimana metode ini dikenal sebagai metode yang dapat digunakan oleh kalangan manapun. Hal ini sejalan dengan input mahasiswa jurusan PAUD yang bukan lulusan sekolah menengah musik.

3. Metode pembelajaran yang digunakan adalah ceramah, tanya jawab, diskusi, pemberian tugas, demonstrasi dan eksperimen, kerja kelompok, drill, dan penemuan. Hal ini sejalan dengan kutipan dalam alamat staff.uny.ac.id/.../default/files/KOMPO

NEN PEMBELAJARAN_29_3_12.ppt yang membahas tentang komponen belajar.

4. Media pembelajaran yang digunakan adalah piano dan berbagai bahan penghasil bunyi yang ada di sekitar kelas yang dapat digunakan sebagai alat musik non vokal. Hal ini sejalan dengan fungsi media.

5. Evaluasi pembelajaran dilakukan diantaranya dengan menempuh adanya ujian tengah semester dan ujian akhir semester yang dilaksanakan pada tatapmuka ke 16 dan 32. Hal ini sejalan dengan kutipan dalam alamat staff.uny.ac.id/.../default/files/KOMPO NEN PEMBELAJARAN_29_3_12.ppt disebutkan bahwa komponen belajar yang diantaranya juga harus ada evaluasi dalam setiap pembelajaran guna menentukan langkah selanjutnya terkait perkembangan anak.

\section{KESIMPULAN}

Berdasarkan hasil penelitian dan pembahasan, maka kesimpulan penelitian ini adalah:

1. Peserta didik berasal dari bermacam jurusan (SMA ataupun SMK). 
2. Materi pembelajaran menggunakan metode Takadimi, metode untuk semua kalangan umur.

3. Media yang digunakan adalah piano dan semua benda di sekitar yang dapat menghasilkan bunyi dengan cara dipukul maupun disentuhkan satu sama lain, diatur sehingga menjadi bunyi musikal.

4. Metode pembelajaran yang digunakan adalah ceramah, tanya jawab, diskusi, pemberian tugas, demonstrasi dan eksperimen, kerja kelompok, drill, dan penemuan.

5. Evaluasi yang digunakan didasarkan pada kehadiran, tugas, ujian tengah semester, dan ujian akhir semester.

\section{DAFTAR PUSTAKA}

Bruce Benward and Marilyn Saker. 2008. Music in Theory and Practice Vol. 1. Eighth Edition. Macgraw Hill.

Ester, dkk. Takadimi: A Rhythm System for All Ages. Music Educators Journal; Nov 2006; 93, 2; ProQuest pg. 60

http://repository.upi.edu/217/6/S_FIS_0807 372 CHAPTER3.pdf.

http://digilib.uinsby.ac.id/7041/4/bab\%203.p df

Miller, Hugh M. (Tanpa Tahun). Pengantar Apresiasi Musik (Introduction to Music a Guide to Good Listening). Terjemahan dari Bahasa Inggris oleh Triyono Bramantyo PS.

Prier, Karl-Edmund SJ. 1996. Ilmu Bentuk Musik. Pusat Musik Liturgi. Yogyakarta.

Safriena, Rien. 1999. Pendidikan Seni Musik. Jakarta. TT

staff.uny.ac.id/.../default/files/KOMPONEN PEMBELAJARAN_29_3_12.ppt. 